\title{
Monitoring the health of sediment ecosystem along the Mahim Creek of Mumbai - A Study of Physico- Chemical Properties
}

\author{
P. U. Singare*, S. E. L. Ferns \\ Department of Chemistry, Bhavan's College, Munshi Nagar, Andheri (West), Mumbai 400058, India \\ *E-mail address: pravinsingare@gmail.com
}

\begin{abstract}
The present study was performed for the period of one year from June 2012 to May 2013 in order to understand the physico-chemical properties of sediments samples collected along the Mahim Creek of Mumbai. The annual average $\mathrm{pH}$ value of the creek sediments was recorded as 9.22. It is feared that such conditions may increase the alkalinity of Creek water which according to USEPA will increase the physiological stress of many aquatic species resulting in decreased reproduction, decreased growth, disease, or death thereby reducing the biological diversity of the Creek. The total organic matter in the creek sediments was found to be maximum of $10.30 \%$ with an annual average concentration of $6.29 \%$. Although organic matter is a primary source of food for benthic organisms and is important in maintaining a viable ecosystem, too much of organic matter deposited in the sediments will be responsible for depletion in dissolved oxygen content of the creek water causing unpleasant odours and may also increase the rate of eutrophication. From the results it appears that as India moves towards stricter regulation of industrial effluents to control water pollution, greater efforts are required to control the discharge of pollutants into the ecosystems.
\end{abstract}

Keywords: physico-chemical properties; TOC; conductivity; sediments; Mahim Creek; Bandra ki Khadi Mumbai

\section{INTRODUCTION}

Although all industries in India function under the strict guidelines of the Central Pollution Control Board $(C P C B)$ but still the environmental situation is far from satisfactory. Different norms and guidelines are given for all the industries depending upon their pollution potentials. Most major industries have treatment facilities for industrial effluents. But this is not the case with small scale industries, which cannot afford enormous investments in pollution control equipment as their profit margin is very slender. Consequently, at the end of each time period the pollution problem takes menacing concern. As a result in India there are sufficient evidences available related with the mismanagement of industrial wastes [1-6].

The industrial wastes often contain a wide range of contaminants such as petroleum hydrocarbons, chlorinated hydrocarbons and heavy metals, various acids, alkalis, dyes and other chemicals which greatly change the $\mathrm{pH}$ of water. The waste also includes detergents 
that create a mass of white foam in the river waters. All these chemicals are quite harmful or even fatally toxic to fish and other aquatic populations.

These wastes also include various toxic chemicals, acids, alkalis, dyes, detergents, pesticides and agrochemicals which greatly affect the physico-chemical properties of water bodies. Therefore, a better understanding of physico-chemical properties like $\mathrm{pH}$, conductivity, alkalinity, salinity, hardness, Chemical Oxygen Demand (C.O.D) etc. in the water bodies seem to be particularly important issues of present day research on pollution assessments. As compared to the usual water testing, sediment testing reflects the long term quality situation which is independent of current inputs.

The suspended and precipitated non-floating substances and organic substances in waters are capable of adhering pollutant particles by adsorption. The sediments, both suspended and precipitated substances stored on the water bottom, form a reservoir for many pollutants and trace substances of low solubility and low degree of degradability $[7,8]$. Pollutants are conserved in sediments over long periods of time according to their chemical persistence and the physical-chemical and biochemical characteristics of the substrata. This can allow conclusions to be drawn regarding sources of contamination. Since sediments act as a sinks and sources of contaminants in aquatic systems, chemical analysis for characterization of sediments also provides environmentally significant information about natural and anthropogenic influence on the water bodies [9-15].

The present study was therefore carried out to understand the physico-chemical properties of the sediment samples collected along the Mahim creek of Mumbai. The results of our study is expected to provide valuable information about the trend in physico-chemical properties of the creek sediments due to pollution load received from the adjoining Mithi River and also from the domestic effluent discharged by the surrounding slum areas.

\section{EXPERIMENTAL}

\section{1. Study Area}

The Mahim Creek (locally known as Bandra ki Khadi) is a creek in Mumbai, India. The famous Mithi River which is one of the most polluted river of Mumbai drains into the creek which further drains into the Mahim Bay. It is the only Creek which balances the water level of Mumbai during heavy rainfall and during Mumbai monsoon time. The creek is the biggest sink for most of the waste generated by residential complexes and small scale industries. The waters of the creek are foul smelling due to the dumping of untreated industrial effluents further upstream.

The creek is swamped by mangroves and has a mini-ecosystem within it. It is a less known fact that the Mahim bay area, where Mahim creek meets Arabian Sea, is a nominated bird sanctuary called "Salim Ali Bird Sanctuary" where migratory birds come for nesting. The Creek is located along western Arabian cost of India from 19 ${ }^{\circ}$ '52.84' north and from $72^{\circ} 50^{\prime} 17.56^{\prime}$ ' east. The depth of the creek is 15 feet $(4.6 \mathrm{~m})$. The area experiences tropical savanna climate. It receives heavy south west monsoon rainfall, measuring $2166 \mathrm{~mm}$ on an average every year. The temperature ranges from $16{ }^{\circ} \mathrm{C}$ to $39{ }^{\circ} \mathrm{C}$ with marginal changes between summer and winter months. The relative humidity ranges between 54.5 to $85.5 \%$. 


\section{2. Requirements}

All the glassware, casserole and other pipettes were first cleaned with tape water thoroughly and finally with de-ionised distilled water. The pipettes and standard flasks were rinsed with solution before final use. The chemicals and reagent were used for analysis were of analytical reagent (A.R.) grade. The procedure for calculating the different parameters were conducted in the laboratory.

\section{3. Sediment sampling and sample preparation}

The study on pollution status along the Mahim creek of Mumbai was performed for the period of one year from June 2012 to May 2013. Sediment sampling was done along different locations of the creek by hand-pushing plastic core tubes with an intention to avoid metallic contamination. Samples so collected were kept in polythene bags which were free from heavy metals and organic impurities. The samples collected in the field were well covered while transporting to the laboratory to avoid contamination from the environment. The samples thus collected from different locations were mixed together to give gross sample. The samples collected were air dried, ground using agate mortar and sieved with a $0.5 \mathrm{~mm}$ mesh size sieve to uniform particle size. The thoroughly mixed sediment samples were packed in polythene bags and kept in a dry place until analysis. The samples were analyzed every month for their physico-chemical parameters so as to get the seasonal variation in pollution level along the Mahim Creek.

\section{4. Quality control/assurance}

Sediment samples were collected with plastic-made implements to avoid contamination. Samples were kept in polythene bags that were free from heavy metals and organics and well covered while transporting from field to the laboratory to avoid contamination from the environment. All glassware used were soaked in appropriate dilute acids overnight and washed with teepol and rinsed with deionised water before use. All instruments used were calibrated before use. Tools and work surfaces were carefully cleaned for each sample during grinding to avoid cross contamination. Triplicate samples were analysed to check precision of the analytical method and instrument.

\section{5. Physico-Chemical Parameters studied}

The sediment samples collected were analyzed for $\mathrm{pH}$, total organic matter and conductivity. The total organic matter (\%) of the sediment samples was measured by Loss on Ignition (LOI) method [16]. The $\mathrm{pH}$ and conductivity of the sediment was measured by preparing the water and sediment mixture in the ratio 1:10 using distilled deionised conductivity water [17].

\section{RESULTS AND DISCUSSION}

The experimental data on physico-chemical properties of the sediment samples collected along the Mahim Creek of Mumbai is presented in Table 1. The annual average values of various physico-chemical properties of the sediment samples are graphically represented in Figure 1. The creek sediment was having minimum $\mathrm{pH}$ value of 9.02 in the month of September and maximum $\mathrm{pH}$ of 9.40 in the month of April, with an annual average 
value of 9.22. The alkaline $\mathrm{pH}$ value of the sediments may results in making the water alkaline. According to the United State Environmental Protection Agency (USEPA) water quality criteria for $\mathrm{pH}$ in freshwater should be in the range of 6.5 to 9 [18].

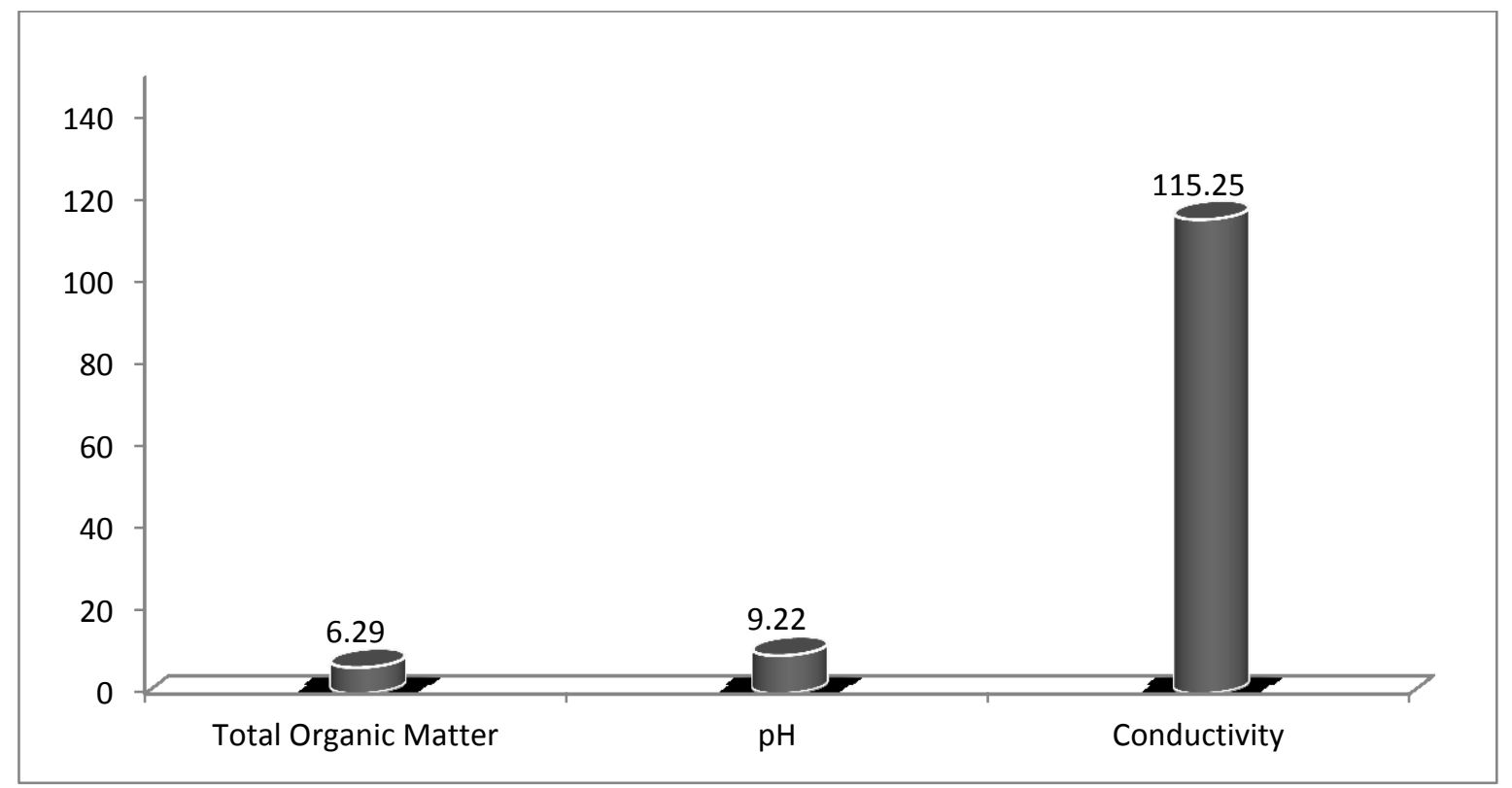

Figure 1. Annual average conductivity, $\mathrm{pH}$ and total organic content in the sediments of Mahim Creek. (Total Organic content expressed in \% and conductivity value expressed in $\mu S . \mathrm{cm}^{-1}$ )

Table 1. Physico-Chemical Properties of Mahim Creek Sediments.

\begin{tabular}{|c|c|c|c|}
\hline Months/Year & $\begin{array}{c}\text { Organic Matter } \\
(\%)\end{array}$ & $\mathrm{pH}$ & $\begin{array}{c}\text { Conductivity } \\
(\mu \mathrm{S} / \mathrm{cm})\end{array}$ \\
\hline June 2012 & 10.30 & 9.30 & 1.24 \\
\hline July 2012 & 7.30 & 9.15 & 36.00 \\
\hline August 2012 & 6.20 & 9.08 & 212.00 \\
\hline September 2012 & 1.89 & 9.02 & 389.00 \\
\hline October 2012 & 2.03 & 9.10 & 396.00 \\
\hline November 2012 & 3.02 & 9.09 & 215.00 \\
\hline December 2012 & 3.97 & 9.26 & 108.00 \\
\hline January 2013 & 5.23 & 9.31 & 23.00 \\
\hline February 2013 & 7.85 & 9.20 & 0.68 \\
\hline March 2013 & 8.12 & 9.32 & 0.69 \\
\hline April 2013 & 9.57 & 9.40 & 0.70 \\
\hline May 2013 & 9.95 & 9.38 & 0.72 \\
\hline
\end{tabular}


Fluctuating $\mathrm{pH}$ or sustained $\mathrm{pH}$ outside this range reduces biological diversity in streams because it physiologically stresses many species and can result in decreased reproduction, decreased growth, disease, or death.

Even small changes in $\mathrm{pH}$ can shift community composition in streams because $\mathrm{pH}$ alters the chemical state of many pollutants, such as copper and ammonia, changing their solubility, transport, or bioavailability. This can increase exposure to and toxicity of metals and nutrients to aquatic plants and animals.

Organic matter is a primary source of food for benthic organisms and it is important in maintaining a viable ecosystem. Sources of organic matter include overland runoff, shoreline erosion (mostly marshes), excessive plant debris or anthropogenic loading and primary productivity within the creek, all of which eventually settle to the bottom of the creek and are incorporated into the sediment. Excess of organic matter can lead to the depletion of oxygen in the sediment and overlying water, which can have a deleterious effect on the benthic and fish communities [19].

The organic matter released into a water body, is used by the bacteria's as food and breaks it down into simpler, less harmful substances. As they do this, the bacteria will use up the dissolved oxygen from the water. This is called deoxygenation. If the quantity of organic pollution is high, then all the oxygen from the water may be used up leading to anaerobic (without oxygen) conditions which may cause unpleasant odours. Total organic matter has a major influence on both the chemical and biological processes that take place in sediments. Total Organic Carbon (TOC) content is proportional to organic matter, which has an affinity for trace metals and organic contaminants.

The amount of organic carbon has a direct role in determining the redox potential in sediment, thus regulating the behavior of other chemical species such as metals [19]. High organic carbon in the northern bays is considered a sign of frequent algae blooms in the overlying water column, the blooms being a result of increased nutrient (nitrogen and phosphorus) loadings into the system. The TOC content in sediments has been used as an indicator of pollution and eutrophication rate [20,21]. In the present study it was observed that the total organic matter in the sediment was found to vary in the range of $1.89 \%$ (minimum) in the month of September and $10.30 \%$ (maximum) in the month of June. The average annual organic content was found to be $6.29 \%$. The conductivity of the sediment was also found to vary in the range of 0.68 to $396 \mu \mathrm{S} \cdot \mathrm{cm}^{-1}$ having average annual conductivity value of $115.25 \mu \mathrm{S} \cdot \mathrm{cm}^{-1}$.

\section{CONCLUSIONS}

With the rapid industrialization in the country, environment pollution by industrial waste has increased tremendously. The industrial discharge of waste water effluents pollutes water bodies. Nature has an amazing ability to cope up with small amount of water wastes and pollution, but it would be hazardous or harmful if billions of gallons of waste water produced everyday are not treated before releasing them back to the environment. It is therefore recommended that the careless disposal of industrial wastes without pre-treatment should be discouraged. Here the right way forward will be to empower the local communities to ensure their right to a healthy environment and ultimately their survival. Hence there is a need that each industry should treat their effluents, in accordance with the legal requirements, before discharging these into the streams otherwise 'Polluter pays' principle should be implemented. Educating the urban as well as the rural mass is another major step to put a 
check on such industrial pollution. Masses should be made aware of the drastic consequences of such industrial pollution on their lives, both directly and indirectly. The existing situation if mishandled can cause irreparable ecological harm in the long term well masked by short term economic prosperity reflected by massive urbanization and extensive industrial growth.

\section{Acknowledgement}

The authors are thankful to Dr. Tomasz Borowski (Editor-in-Chief) ILNS, for his valuable suggestions which has helped us in improving the manuscript to much better extent.

\section{Biography}

Pravin U. Singare completed his Masters in Inorganic Chemistry (1997) and his PhD in Chemistry (1999), both from University of Mumbai, India. He has worked at Sikkim Mining Corporation, Sikkim, India, on a project related to the concentration of $\mathrm{Cu} / \mathrm{Pb} / \mathrm{Zn}$ sulfide ores. He is currently an Assistant Professor in Chemistry at Bhavan's College, Andheri, Mumbai. His research areas of interest are radioanalytical nuclear chemistry, ion exchange techniques and environmental analysis. He is a member of several scientific societies such as ISAS, NAARI and INS all from BARC, Mumbai, and the Indian Council of Chemists, Agra, India.

Sunny E. L. Ferns has completed his B.Sc. degree from University of Mumbai. At present he is working for his Masters degree (By Research) at University of Mumbai. He has presented number of research papers in National and International Conferences.

\section{References}

[1] P.U. Singare, R.S. Lokhande, A.G. Jagtap, International Journal of Global Environmental 11 (2011) 28-36.

[2] R.S. Lokhande, P.U. Singare, D.S. Pimple, World Environment 1 (2011) 6-13.

[3] S.K. Sasamal, K.H. Rao, U.M. Suryavansi, International J. Remote Sensing 28 (2007) 4391-4395.

[4] A. Nagaraju, S. Suresh, K. Killham, K. Hudson-Edward, Turkish J. Eng. Env. Sci. 30 (2006) 203-219.

[5] T. Rajaram, A. Das, Futures 40 (2008) 56-60.

[6] P.U. Singare, S.S. Dhabarde, International Letters of Chemistry, Physics and Astronomy 3 (2014) 56-63.

[7] C. Biney, A.T. Amazu, D.Calamari, N. Kaba, I.L. Mbome, H. Naeve, P.B.O. Ochumba, O. Osibanjo, V. Radegonde, M.A.H. Saad, Ecotoxicol. Environ. Safety 31 (1994) 134-138.

[8] M.T. Barbour, J. Gerritsen, B.D. Snyder, J.B. Stribling, USEPA Rapid Bioassessment Protocols for Use in Streams and Wadeable Rivers. Periphyton, Benthic Macroinvertebrates and Fish., Second Edition. EPA/841-B-98-010. U.S. Environmental Protection Agency; Office of Water; Washington, D.C. (1998).

[9] R.S. Lokhande, P.U. Singare, D.S. Pimple, The New York Science Journal 4 (2011) 66-71. 
[10] P.U. Singare, M.P. Trivedi, R.M. Mishra, American J. Chemistry 2 (2012) 171-180.

[11] P.U. Singare, R.M. Mishra, M.P. Trivedi, Advances in Analytical Chemistry 2 (2012) 14-24.

[12] N. Menounou, B.J. Presley, Arch. Environ. Contam. Toxicol. 45 (2003) 11-29.

[13] D.R. Spooner, W. Maher, N. Otway, Arch. Environ. Contam. Toxicol. 45 (2003) 92-101.

[14] S.K. Sahu, P.Y. Ajmal, G.G. Pandit, V.D. Puranik, J. Haz. Mat. 164 (2009) 1573-1579.

[15] P.U. Singare, M.S. Talpade, D.V. Dagli, V.G. Bhawe, International Letters of Chemistry, Physics and Astronomy 8 (2013) 105-112.

[16] E.E. Schulte, B.G. Hopkins, Estimation of soil organic matter by weight loss-onignition. In: F.R. Magdoff, M.A. Tabatabai, E.A. Hanlon, Jr. (eds.), Soil Organic Matter: Analysis and Interpretation. Soil Sci. Soc. Am., Madison, WI, p. 21-31 (1996).

[17] M. Radojevic, V.N. Bashkin, Practical Environmental Analysis. The Royal Society of Chemistry, (UK.) p. 466 (1999).

[18] US EPA, CADDIS Volume 2: pH Sources, Stressors \& Responses.

Obtained through the Internet: http://www.epa.gov/caddis/ssr_ph_int.html [Accessed on 15/05/2014].

[19] D. Well, in: Total organic carbon in Maryland Coastal Bays sediments: Status of a regulator of chemical and biological processes, Chapter 5.1, Maryland's Coastal Bays: Ecosystem Health Assessment. Obtained through the Internet: http://www.dnr.state.md.us/coastalbays/publications/Chapter5.1.pdf [Accessed on 15/05/2014].

[20] U.S. Environmental Protection Agency (EPA), Mid-Atlantic Integrated Assessment (MAIA) Estuaries 1997-98: Summary Report, EPA/620/R-02/003, p. 115 (2002).

[21] Pravin U. Singare, M. V. A. Ansari, N. N. Dixit, International Letters of Natural Sciences 11(1) (2014) 54-61. 